\title{
Smart Villages: Comprehensive review of initiatives and practices
}

\author{
Veronika Zavratnik, Andrej Kos, Emilija Stojmenova Duh \\ University of Ljubljana, Faculty of Electrical Engineering, Tržaška cesta 25, 1000 Ljubljana, \\ Slovenia; veronika.zavratnik@ltfe.org_andrej.kos@fe.uni-lj.si; emilija.stojmenova@fe.uni-lj.si
}

\begin{abstract}
Over the recent decades people's (rural and urban) communities are facing numerous social and economic changes and challenges. Some of those challenges have been increasingly addressed through the lenses of technological developments and digitalization. In this paper we have made a review of already existing practices while focusing on the existing implementations of the smart village concept and the importance of digital transformation for rural areas. We give special attention to EU policies which we are using as an already existing framework for understanding our own forthcoming examples. We have shown the parallels between the findings and insights from different regions and made an evaluation of presented practices. Our main argument stems from our own previous experiences and experiences of other research approaches, and is grounded on the argument that rural areas are not uniform, and that smart rural development has to be applied in combination with place-based approach. We present the cases of Slovenian pilot practices and support our argument by proposing the FabVillage concept.
\end{abstract}

Keywords: smart villages; smart development; sustainability; digitalization; ICT

\section{Introduction}

One of the most important and accurate questions that contemporary societies have to address is how to make people's communities and their settlements more sustainable. Evermore aspects of most societies and their economies are inextricably linked to changes brought forward by technological developments that are transforming people's everyday routines, perceptions of the environment, access to the electricity, food, health, education and many other. To properly address those changes in 2015 the 2030 Agenda for Sustainable Development (the so-called \#Envision2030) was adopted by the General Assembly of the United Nations, and it included seventeen Sustainable Development Goals (SDGs) [1]. As will be detailed later on, the Agenda took a holistic approach to sustainable development for everyone and in every segment of life, including education, employment, inequality, accessibility of settlements etc.

One part of the answer towards achieving higher levels of sustainability and SDG is to find the right ways on how to deal with economic disparities, climate changes, accessibility to modern technologies and other necessary infrastructure. Considering the (dis)advantages of some already existing practical approaches, one of the most promising ways is to make them smart(er). Disregarding the somehow vogue meaning of the "smartness" $[2,3]$ in general that will be explained later on, it is important to note that the concept for urban smart communities is already very well established - e.g. smart cities, but less so for rural communities as the concept smart village has only recently gained momentum; for example, in EU the Smart Village Initiative was launched by the European Parliament in 2017, and the EU Action for Smart Villages document was published by the European Commission together with the European Parliament. Moreover, 'Smart Villages' was initiated as a subtheme within the European Network for Rural Development (ERND) work on 'Smart and competitive rural areas' between September 2017 and July 2018 [4].

The main objective of this paper is to review and discuss already existing initiatives and projects on rural development and especially on smart villages in Europe and broader. In order to understand 
the influences of smart development and how communities embraced it, it is necessary to make a review of the practices, policies and initiatives. Only then we can use and apply the concept into new environments more successfully.

What is a smart village?

The so-called smart development of infrastructure is hardly strictly divided into two polarized sets of frameworks, rural and urban. As is vividly described by P. Srivatsa [5] in the case of Indian smart development, it is necessary to consider both spaces simultaneously, their mutual interconnections and take into account that significant changes in one will affect the other and another way around. Therefore, the paper considers both contexts and combines the findings from the two.

What exactly do we mean by talking about smart development, smart cities or smart villages? Is there any clear definition of a smart community?

Firstly, no, there is not one clear and definite definition of neither one [6]. As communities are not a "thing", inanimate and unchangeable, and are thus always dependent of the environment and changes in socio-cultural structures, there cannot be a one-size-fits-all proposed definitions. Every proposed definition is dependent upon different circumstances, societal problematics and reflects difficulties encountered by each individual community. For example, discussing the smart growth plans in Wisconsin, USA, Edwards and Haines define six smart growth goals that were most widely incorporated into smart growth plans in the Wisconsin case. In their contribution they emphasize i) creating new housing choices and opportunities, ii) making communities more accessible by foot, iii) enforce the sense of place in communities, iv) preservation of different environmental zones, v) connect new and the existent developmental aims, vi) more varieties in terms of transportation [3]. On another hand: European Union is moving towards the application of the "smart" growth on the wings of a "knowledge based economy" [7] (pp. 56-58).

Secondly, even though the implications of technologies are often used in discourses on smart communities, the technological and digital components of the transformation are not the only ones, not necessarily the most important in specific cases. Annamária Orbán is making a report on smart and self-sustaining rural villages in Hungary on the example of Túristvándi, a small village that began its journey towards the label 'smart village' in the field of agriculture and with the decision to become self-sufficient in food production [8] (pp. 678-680). On the basis of smart/successful agricultural decision, the education level of the village inhabitants has increased, the population has grown, and health services improved. As is claimed by Jucevičius et al. [2], a more detailed and comprehensive analysis of initiatives and practices of smart social system brings to the fore the important finding that while looking at the smart system it is not always the case that they are grounded on the information and communication technologies (ICT). In the proposed model, instead they are focusing more on the relationships with the environment. But even though the digital dimension does not pervade all the models of the smart cities/ villages and its main features, it is indeed important to all of them [9] (pp. 149).

Thirdly, and stemming from the above claims, smart dimension of the development might not always be addressed under the label "smart" but could also be intertwined with other dimensions, as in the case of SDG where smart dimension is addressed in most of them addressing other specific aspects: sustainability, well-being, (inclusive and equitable quality) education, empowerment of women and girls, management of water resources, accessibility of sustainable energy, sustainable economic growth and decent work, building resilient infrastructures, fostering innovation, reducing inequalities, making human settlements more inclusive and sustainable, taking actions to combat climate change, protecting ecosystems, etc.[1].

Slipperiness of trying to precisely define the smart development per se, allows us to propose only vague, very broad definitions of smart communities. This is so because the classifications are always case dependent and based on given, specific conditions (e. g. locality, geographical conditions, (social and natural) resources) and influenced by most visible challenges that communities face [10] (pp. 177). 
Smart city is an urban living environment, build or upgraded/ renovated [9] to enable the best possible coordination for otherwise fragmented urban sub-systems, and to facilitate everyday lives of inhabitants, making cities more liveable and sustainable [11]. Very broad definition proposed by Cohen states, that "smart cities use information and communication technologies (ICT) to be more intelligent and efficient in the use of resources, resulting in the cost and energy savings, improved service delivery and quality of life, and reduced environmental footprint - all supporting innovation and the low-carbon economy" [10] (pp. 178). The most representative features of the smart city are shared ICT structures, time optimization, open government, energy efficient technologies, reduced emissions, orientation towards green environment $[13,6]$.

If the transition to smart infrastructure is important for urban living environments, this transition is even more necessary and complex in the case of more sparsely inhabited areas. To identify challenges and their potential solutions in this cases, it is necessary to use local and regional knowledge and implement it. More precisely, in the context of European Union, the concept smart villages refers to "rural areas and communities which build on their existing strengths and assets as well as on developing new opportunities. In Smart Village traditional and new networks and services are enhanced by means of digital, telecommunication technologies, innovations and the better use of knowledge for the benefit of inhabitants and business" [14]. To sum up, to apply the smart village concept, it is necessary to use bottom-up integrated approaches, build effective public-privatecommunity partnerships, develop supportive policy frameworks and enable access to financing mechanisms [15]. The crucial point in the process is to put the communities themselves behind the steering wheel and not impose developmental paradigms that would not be compatible with community's desires and cultural environments.

Smart village enables its inhabitants to make use of the contemporary technological and social achievements, while its infrastructures are still being developed in line with Sustainable Development Goals, offer an opportunity to efficiently deal with future of energy security and issues of local and circular economies. But as it will be shown later on in the case of Indian Smart Cities and Smart Villages, to treat smart villages as an autonomous and independent entities poses a threat to only partial understanding of the framework. Instead, the interspatial dimension is of great importance. Therefore, this paper, although focusing primarily on the smart rural development and smart villages initiatives, constantly draws the parallels with smart cities, towns and national developmental policies. Within the smart development discourse, at the forefront of this paper will be the consideration of the perspectives of the digital transformation of the rural environments.

\section{Worldwide initiatives on Smart Villages}

Seen in the worldwide context, there are several initiatives promoting or using the concept of the smart villages.

Smart village initiative: New thinking for off-grid communities worldwide [16] and IEEE Smart Village: Empowering off-grid communities [17] are both worldwide active and striving to meet the SDG 2030, especially the goal 7, Affordable and Clean Energy. The first one promotes access to sustainable energy as a main catalyst for the development of good education and healthcare systems, access to clean water, sanitation, economic growth, enhanced security, gender equality etc. The most important vision of the Initiative is to apply more holistic and integrated approaches to enable the access to the energy in the rural contexts, while connecting/involving governments, developmental and private sector in the process. The component most emphasized is how to connect renewable sources of energy with ICT [15]. The activities of the Initiative are taking place in six large regions, namely East Africa, West Africa, South Asia, South-east Asia, South America, and Central America, Caribbean, Mexico - the so-called developing world with limited possibilities to access (educational, electrical, economic and other) infrastructure. To find the most suitable solutions there is a wide range of professionals working on the field and otherwise: villagers, NGOs, development organizations, entrepreneurs, policy makers, engineers, experts from the field of humanities. [55] Their search for solutions is encompassing and based on a long term research, analyzing local and regional circumstances, identifying cross-cutting issues and proposing suitable solutions. More than 30 
workshops have been organized where more than thousand stakeholders from 70 countries have presented their views and evidences. [16] (pp. 140) By now the most part of their activities was funded by Cambridge Malaysian Education and Development Trust and Malaysian Commonwealth Studies Centre.

Similarly, the IEEE Smart Village initiative is aiming to promote off-grid communities through education and the creation of sustainable businesses in the energy sector. Initiative was originally established as Community Solutions Initiative (2009) and took over the current name in 2014. The activities are spread worldwide, by now serving more than 50000 people, living in 34 villages, mostly located in African continent (e. g. Benin, Cameroon, Kenya, Malawi, Namibia, Nigeria, South Sudan, Zambia), but also in Haiti and India. [56] Its main financing mechanism is fundraising. Besides the development of energy-smart villages mentioned before, the main products of the initiative's efforts are a SunBlazer II - mobile solar-based power base station and Learning beyond the Light Bulb - a nine month program of remote study that enables the exchange of practices of all communities in order to create the mutual benefit, and equips the students with knowledge on different development models and other skills and knowledge needed for the fieldwork.

One of the most propulsive worldwide programs is the CIGAR research program on Climate Change, Agriculture and Food Security that started in 2011 [33, 34].The program is funded by CIGAR fund and different donors (e. g. Australia, Irish Aid, Netherlands, New Zealand, Switzerland, Thailand, UK Aid, US Aid, EU, The International Fund for Agricultural Development). Within its framework the concept of climate smart villages is being developed and put into practice in the different parts of the world, whereas the ones with the most climate-related difficulties are chosen (West and East Africa, Latin America, South and Southeast Asia). This is an ever evolving program where different stakeholders (researchers, politicians, framers, local residents) are collaborating in order to find the most productivity enhancing and smart solutions considering the local conditions. Their solutions are based on smart technologies and services, designed in collaboration with local people, and aim at lessening the climate footprint from the perspective of the developing agricultural activities, while not reducing their benefits for the given community. The Program is claimed very successful, as there is more than 30 existing climate-smart villages all over the globe. More importantly, the villages are on the good way to be sustainable in the long term as the program aims to train the local people and not providing locals with the external teachers on the long-term basis. Within this objective, an important role is also played by women. One of other practical outputs of the program is for example CCAFS Climate Analogues Tool for making rain and climate predictions, developed to help smaller farmers make decisions based on accurate information. [57]

Perhaps one of the most extensive and most recent attempts of smart transformation development is India. Firstly, urbanization of India is increasing rapidly as never before. According to the predictions of the United Nations, by 2050 almost 814 million of Indian people will live in the towns and cities which is twice as many as today [10]. Secondly, in 2015 the Government of India, Ministry of Urban Development launched a nationwide program Smart city mission [20]. The aim of the Mission is the comprehensive development of (physical, institutional, social, economic) infrastructure, and thus improvement of the quality of life and to attract people and investments. The governmental mission covers 100 cities, selected in the "City Challenge" process, but also recognizes that there is no single definition of the smart city that would encompass important factors for all the different cases and therefore aims to set the examples that could be replicated in various regions and cities within the country. Thirdly, smart city initiative was supplemented by Indian SmartVillages Initiative [21] aimed at harness the benefits of ICT for the people living in the rural sites. Despite the urbanization processes, in India around $67 \%$ of population still lives in the rural areas, but ruralurban migrations are posing big problems in India [5] (pp. 4). For example, according to the estimates of Indian Ministry of Statistics and Programme Implementation, in years 2009/2010 more than 60\% of the male rural-urban migrations was due to employment related reasons. Agriculture holds only minor part in Indian economy (e.g. around 17\%), compared to services sector that is flourishing (almost 54\%). [58] As it has been stated by Srivatsa, to somehow maintain the "equilibrium" between the urban and rural areas, the smart development of both has to be parallel and simultaneous. In this 
way the large migration from rural to urban areas can be limited or even stagnate. [5] (pp. 4) It is anticipated, that carefully designed smart villages will provide a basic framework for local people to enhance their participation on a local level and to improve their economic, social and living conditions and thus make their community stronger and more flexible for the challenges of the outside world [5](pp. 8). Within the "Digital India" plans, Indian government envisages that by the year 2019, 250000 Indian villages will have the access to the internet and telecommunications networks. [22]. Therefore, there is a need to design and develop villages that have established good endo- and exogenous connections, e. g. they have good connections to the outside world but at the same time they maintain their independence in providing employment and services. To summarize, in Indian case two approaches are used as being complementary, smart villages serving as engines to smart cities economic growth, by producing services and goods for rural but also for wider (inter)national markets. Unfortunately there is no synthesis on how many smart villages has already been developed/ established in India, there are only some fragmented lists and websites dedicated to specific villages which makes it difficult to keep up with the numbers.

Closer look at the above presented initiatives working at the worldwide level enables us to make some very broad conclusions. Looking at the main objectives and activities taking place within their frameworks, but also regarding to some other reports $[18,19]$ and models, energy sector lies at the core of dealing with sustainable and smart community development. Even though the focus on sustainable energy supply is not explicitly in the forefront of the global developmental initiatives, it is implicitly involved within other objectives, such as lessening the climate footprint of agricultural practices. As it will become more evident in the next subchapter, closer look at the European practices reveals also that focus areas of global initiatives have different social and economic conditions and therefore propose different solutions adapted to needs of the communities. Whereas global initiatives are primarily focusing on the areas with the lack of basic infrastructure (electricity, water supply, internet access, etc.), the European initiatives are working in the areas with basic infrastructure already provided and are therefore addressing different challenges of smart and sustainable development through products and services with social, economic, and environmental benefits. EU policies, initiatives and examples

In line with the described global initiatives and tendencies towards smarter and more sustainable communities, the European Union has also taken a holistic and integrative approach towards those objectives.

The first step specifically connected to smart villages was made in 2016 when the Cork Declaration 2.0, has been proposed (Cork, Ireland), under the name A Better Life in Rural Areas [25]. The declaration has very openly addressed some concerns about the state of the rural areas, specifically rural exodus and youth drain and thus paved the way for further orientations of future policies, including smart villages' agenda. Through the ten points of addressing problematics of rural spaces, one of the main conclusions was that investment in rural areas is necessary, especially in the sense of encouraging of their identification processes, acknowledging their potentials for (economic) growth and ensuring that they will become attractive places for people of all ages to live in and work at. Particular attention has also been paid to overcome the digital divide between rural and urban spaces and developing the potential of digitalization in rural areas.

In the following year, 2017, European Commission launched EU Action for Smart Villages [14] with the purpose to initiate some reflections on the villages of the future. Besides some funds and policies that have already existed before (e.g. Common Agricultural Policy, Rural development policy, EU Cohesion Policy) some new have been proposed: European Innovation Partnership for Agriculture (EIP-AGRI) that is directed towards development in the field of forestry and food production and The European Network for Rural Development (ENRD). In order to promote smart villages the plan proposed 16 actions suggesting organization of some workshops/ seminars/ conferences, thematic groups, new platforms (e.g. Smart specialization platform agri-food), setting up new offices (like Broadband Competence Offices), and very importantly, also suggesting some projects on SMARTA (Smart Rural Transport 'Areas') and Smart Eco-Social Villages. The latter was specifically focusing on connectivity and digital solutions, but more broadly it was aimed at exploring 
some basic features of smart eco-social villages and identifying best examples that could be used in rural communities by decision makers in order to build future strategies.

Very recently, in April 2018 another declaration was accepted: Bled Declaration (Bled, Slovenia). The Declaration acknowledges "that the rural digital economy, if developed in an innovative, integrated and inclusive way, has the potential to improve the life-quality of rural citizens and, thereby, contribute to tackling the current depopulation of- and the migration from- rural areas." [26] The Declaration proposed some actions to reach better conditions for developing farming enterprises and new service sector; the two are addressing the rural Youth Drain, and will be providing the opportunity for the youth to return back home after finishing their studies and pursue white-collar jobs to further their specialization in their local area. By creating synergies between some technological achievements (precision farming, digital platforms - e-learning, e-health, eadministration etc., shared economy, circular economy, bio based economy, rural tourism, social innovation) the Declaration called for some smart villages to become a role model for further developments already in the following year, 2019.

Further, another document that has an important impact on the development of European rural areas is Rural Development policy 2014-2020 [27] that devotes separate attention to specific European regions, contributing funds to their own rural development programs tailored to their regional needs. The policy was designed to meet contemporary challenges in the sphere of environment, economy and in the society, and is worth 100 billion euros. Every program designed within the policy addresses minimum four of EU priorities for rural areas, oriented towards either fostering, enhancing, promoting innovative and knowledgeable ways towards social agriculture, forestry, food production, agricultural ecosystems and resource efficiency, or development of rural areas into the front. [27]. Within this European policy and national programs, the LEADER approach is also being implemented. LEADER method was already launched in 1991 [37] and was recently extended with more encompassing Community-Led Local Development (CLLD) [38]. The main characteristic of the approach is its focus on the local communities and acceleration of the solutions that are based on the bottom-up local initiatives. Cooperation on different levels is also being encouraged, connecting private and public sectors within the region (in the form of Local Action Groups - LAG), within the country but also between different EU countries. In the programming period 2014-2020 altogether there is already 2600 Local Action Groups (LAG) that are implementing the LEADER approach, which makes it a successful practice. Solutions that are based in the local environments and use local/ regional resources are in line with designing the so-called smart developmental solutions and therefore the LEADER approach is an important factor in recognizing such practices.

European Spatial Planning Observation Network (ESPON) 2020 Cooperation Programme is another program adopted by European Union, aiming at reinforcing the effects of European Cohesion policy. ESPON strategy is inextricably connected to the European rural areas. For example, in the policy brief Shrinking rural regions in Europe [35] it is recognized that rural areas in the EU are shrinking or facing depopulation (pp. 4) and the policy urges to see such processes in the broader light and recognize also the possibilities not only the dangers of such processes. ESPON 2020 has been preceded by ESPON 2013 and ESPON 2006, all of them supporting EU vision on territorial cohesion and steady development of all regions but each setting their own specific priorities [36].

Regarding EU measures it is important to note, that considering the rural development, abovementioned recent policies and measures were preceded by some important strategies - such as LEADER approach and the actions taken to better understand also the mutual connection between rural and urban places in Europe [39] that have been addressed in line with the European cohesion actions. The latter has specifically addressed the relationships between the rural and urban regions, their intensive and interdependent relations, and extensive changes they are going through in the last decades. Within this framework the need for mutual co-development has been noted and some corresponding actions taken: Study Programme on European spatial planning, ESPON strategy, the project RURBAN (in 2010).

Within all the above mentioned EU policies and other measures, there have been numerous (re)actions connected to the creation of smart communities, and we are presenting only some of them. 
One of such initiatives that serves as an example and offers a deeper insight on how to apply the concept of smart development to a specific regional context has already been mentioned - the case of Hungarian Túristvándi. Their already mentioned smart developmental strategy has had several phases, starting in 2001 when the village participated in Social Land program and started investing to make local food production self-sufficient. [8] Later (between 2012 and 2014), the Túristvándi and whole Észak-Alföld region were included in the INTERREG project named SMART EUROPE (Smart strategies to create innovation-based jobs in regions of Europe) that was funded by ERDF (January 2012 - December 2014) and was worth more than 1, 8 millions $€$. [45] Amongst others, the case of Túristvándi was listed as an example of the good practice 'Job-creating practice cooperation between triple helix actors: Self supporting village of Túristvándi' starting in 2006. [46] As the result of all the efforts, the villagers were able to restore their ancient water mill - the main tourist attraction and therefore establish some new tourist capacities and attract big numbers of tourists (more than 40000 ). [8] (pp. 680) North Great Plain (Észak-Alföld) region is typically characterized by rapid aging of the population, high unemployment rate and traditional agricultural activities [50] from which stems the need to develop more accurate and smarter ways of dealing with the regional problematics. In the case of the aforementioned Túristvándi the development of the touristic potential and local and selfsufficient agriculture is reasonable and smart move for the future.

Further, there is Italian "Smart Basilicata" project [12, 28], funded by Cohesion Fund of the Basilicata Regional authority. The Basilicata region has been struggling with the decline in GDP and one of the highest unemployment rates in Southern Italy. In 2015 great part of the regional enterprises was working in the field of agriculture (32\%, which is more than is the national average). A great majority of region (92\%) is either farmland or forests. [51] Besides everything mentioned, Basilicata is also one of two most sparsely populated regions, with 56,6 people/km2 [52] which is also the consequence of mountainous and hilly territory. The main aims of the project were to make region more sustainable and resilient, which was done building on local and regional knowledge. The Smart Basilicata project identified the main difficulties, searched for possible practical solutions and ways to put them into practice. This was done through five pillars of Basilicata as a smart region: natural resources, energy, mobility, culture and tourism, smart participation [12] (pp. 1028). The duration of the project was 54 months (2012-2015) and has made some visible contributions to enhance regional smart development. One of the most accessible is the development of innovative tool to enhance active engagement of citizens in decision-making and encourage public participation through the use of ICT technologies that was developed by using SUN4Matera approach. [53]Another example offering an insight at how to implement the smart village concept is German project Digital Villages (Digitale Dörfer), taking place between 2015 and 2019. The project was funded by Ministry of Internal Affairs and Sports Rhineland-Palatinate with the total budget of around 4, 5 million euros. [29, 30] Majority of the people in Germany lives in rural areas (63,3\%) [41] and therefore applying the smart strategy for the rural development is in line with country's general development goals. The region is one the $6^{\text {th }}$ richest German region and its economy is largely based on chemical and pharmaceutical sector, vehicle construction, mechanical engineering and food sector. The region is also very well connected and its broadband coverage is even above the country's average. [54] At the fore of the program is the digital transformation of the three chosen communities Eisenberg, Gollheim and Beztdorf-Gabhardshain (altogether this is 33 municipalities). The main objectives of the project are to encourage innovation, collaboration (residents-local authorities-local industry), and cross-sectoral, sustainable and affordable solutions. Through using the living-lab-approach target domains were chosen and according to this, several solutions have been proposed: local online marketplace, local news portal and digital platform. BestellBar, an online market place included more than thirty local vendors and 700 residents registered in only three months of its existence. Similar success was shared by an online local news portal where up to 400 users was recorded per week. [30] The course of the project is deemed successful and some of the cues for similar projects are worth noting: it is good to have local contact persons; it is necessary to gain trust of the villagers; recognizing people's needs is the starting point; permanent involvement is crucial; prototypes are important [41]. 
Another very extensive initiative on smart digital transformation is connected to one of the Arctic areas, Lapland is carried out within the framework of the ERD funds since 2014. Under Arctic Smartness Project, the project of Regional Council of Lapland, there is five distinctive clusters operating in different but interconnected domains: Arctic Industry and Circular Economy, Arctic Development Environments, Arctic Design, Arctic Safety and Arctic Smart Rural Community Cluster (Rural Cluster) - especially the latter being part of our more detailed discussion. [47, 48] Within the Arctic Smartness the economic and business opportunities of the region are being improved therefore enhancing Lapland's economic competitiveness. One of the main areas addressed through the Rural Cluster is connected to the sustainability of renewable energy and natural resources, and local food production. Local authorities, entrepreneurs, developers, researchers, education and some other institutions are connected in the network and coordinated by the cluster to enable the smart and sustainable development of the area. Lapland being the most northern EU region, sparsely populated (with 1,8 inhabitants/ $\mathrm{km}^{2}$ ) and in great majority covered with forests areas (98\%) embraced the possibilities of EU funding (especially the ERD and EARD funds) and started intensively developing (inter)national and (inter)regional partnerships, attracting new organizations and entrepreneurs. The Rural Cluster has also been awarded a Silver Label in the cluster analysis. By now this has developed to be a network consisting of approximately 100 entrepreneurs and around 200 other institutions (such as municipalities, financiers, politicians, advisors etc.). Especially good practice is REKO food circle, an electronic sales channel used by local food producers for selling food directly to the users; by now 100 producers is included. [48] While the most profitable economic sectors are mining, (nature based) tourism and metal and forest industry, the Food Program of the Rural Cluster Strives to increase the regional food self-sufficiency. Discussion: (Smart) villages in practice

It has already been noted that the implementation of smart concepts into regional, both rural and urban contexts has to be adapted to socio-cultural and environmental circumstances. Thus, in the cities different issues need to be tackled than in rural areas, where the main challenge is to bridge the distances among relatively small number of people. In the context of digital transformation that is at the forefront of our interest, this means that also digitalization requires adapted concepts, business models and solutions that have to strive to generally improve the well-being of the rural population.

In the context of this paper we are concentrating on Slovenia as a part of Alpine space region, thus also sharing its problematics. In this regional view a need for strategic approach towards some major challenges has been noted. Towards 1. Economic globalization, 2. Demographic trends, 3. Climate change, 4 . The energy challenge, 5. Alpine region as a transit region. As a solution to the above listed problematics the project Smart Digital Transformation of Villages in the Alpine Space (SmartVillages) has been proposed and also approved for funding (Interreg Alpine Space funding) in 2018. The partnership consists of 13 partners from six countries included in the Alpine space region (Italy, Austria, Germany, France, Switzerland, Slovenia), thus covering a great majority of the regional territory.

Main challenges that SmartVillages project is addressing are in line and complementary to sustainable development goals, EU Action for Smart Villages, EU Rural Development Policy, and proposed objectives of the Bled Declaration. More precisely, it addresses the causes for (youth) brain drain in the region: deprivation of jobs, provision of services, favorable climate for entrepreneurship and social innovation. ${ }^{[1]}$ The project aims to bring together stakeholders from different sectors and to improve the quality of live in villages and small cities through sustainable solution facilitated by ICT.

It is necessary to learn and draw on good practices from other countries, but meanwhile it is also necessary to consider local and regional frameworks within which the implementation of the smart village concept will take place. As it has already been noted by others [40] what is also of vital importance is the quality of rural life. The perceptions of the important building blocks are - once again - locally/ regionally conditioned. Therefore, similar to the concept of the "smart" development 
the quality of life or well-being of the people are also very slippery and hard to precisely define. In line with the abovementioned challenges of the Alpine space region, it is necessary to recognize and address the main reasons for the youth brain drain. Moreover, not only to identify the indicators for the quality of life in the chosen area, but also to evaluate their accessibility is essential in understanding the real-life situations. [40]

In Slovenian context, besides the aforementioned steps, the successful implementation of the concept is dependent upon the integration of the already existing good practices and initiatives that are adapted to local circumstances and are in line with the smart village concept. Bellow we will show how a successful integration of a Fab City $[42,43]$ concept developed in and for context of urban places can be adapted for the use in the rural contexts if based on the grass roots initiatives and an already existing infrastructure.

Fab Cities are cities striving to self-sufficiency in terms of producing what is consumed (also through the mechanisms of FabLab production and know-how solutions) and using locally sourced materials (also obtained with the mechanisms of recycling and digital production. [43] (pp. 465) Fabrication laboratories or FabLabs [32, 44] are creative-learning spaces, usually established by the bottom-up principle that aim to encourage innovation and creativity in approaching different subjects. They also aim to reach people of all ages. Regarding this, one of the most important, already existing infrastructures is a national FabLab Network Slovenia [44]. Namely, to undertake the project that focuses on digital transformation and digital services in particular, it is essential to have or to build up an innovation infrastructure. Network already connects more than 80 partners from different sectors, amongst them more than 20 fabrication laboratories (FabLabs), e.g. Moreover, the Network aims to bring modern digital technologies closer to rural communities and enable them to develop 21st century skills and competences. FabLab network serves as a prototyping and experimentation environment of Digital Innovation Hub Slovenia (DIHS), part of the pan-European network and one of the planned EU actions to promote smart villages. More specifically, in Slovenia there is a number of Fablabs existing in rural places, most of them established on the basis of the grass-roots initiatives. As it was already noted by some authors [32] Fablabs operating in rural areas are creative and innovative places, open to different stakeholders and thus enabling new opportunities for local people, especially the young, and local businesses, especially start-ups, providing them with the space and the infrastructure to gain high quality skills or realize their own business ideas. Fablabs located in the smaller, rural places are enabling local/ regional potential on the basis of local intellectual, natural, infrastructural and social resources and thus providing longterm and sustainable development

Secondly, the Alpine space region has a high touristic potential and a great variety of natural and cultural heritage resources. Sparsely populated areas and diverse geographical terrain make conditions to develop touristic infrastructure challenging. In line with preservation of natural heritage, limited tourist facilities and guidelines of Bled Declaration the development of eco-, health, recreational-tourism is part of the rural tourism strategy. In Slovenia, the concept of distributed hotels is already very well established [31] and experiences will be used to implement and develop it further it in new localities. Distributed hotels are part of green tourism and circular economy, aiming at including local inhabitants into the process of development. In such initiative the local services and resources are used to accelerate local economy. By providing accommodation dispersed in different locations, the concept requires cooperation of the whole community to be sustainable. Tourism development brings new job possibilities, new infrastructure as well as more lively social connections to the region. At the same time sustainable approach to tourism development will help preserving, presenting and celebrating local and regional cultural characteristics and heritage, increasing their universal value and potentials. Such development policies are in line with the objectives of the European Year of Cultural Heritage.

By combining both described initiatives we are aiming to promote the so-called FabVillages that strive to promote the principles of circular economy, locally sourced materials, development of local (natural, cultural, social) resources and economy are thus a good example of how to apply smart development in rural communities to make them more sustainable and resilient. 


\section{Conclusion}

Over the recent years the challenges arising from the social and economic, but also wider changes of people's communities - rural and urban - have been increasingly addressed through the lenses of technological developments and digitalization. In this paper we have focused on the applications of the smart village concept and the importance of digital transformation for rural areas, always drawing parallels between the findings and insights from different regions. We aim to use these new insights in developing the framework of the international project Smart digital transformation of villages in the Alpine Space.

One of the aims of our paper was also to make a qualitative evaluation of the projects and initiatives presented. Considering the initiatives active worldwide we have made a comparison of the territories they cover and areas of actions they are focusing to and concluded that the most important issue to address when making the development strategies for the so-called un-developed countries is the access to the sources of energy. Further, in order to make the concept of "smart development" more accessible and useful for our case of smart villages we have made an evaluation of the projects and programs based on criteria that define "smartness" in the broader sense within the framework of EU policies. For deeper understanding of smart development in specific European regions it is important to make an in-depth analysis of different possible approaches. Below we are presenting a short analysis of the chosen examples according to the EU pillars/ drivers of smart villages: i) Responding to depopulation and demographic change, ii) Finding local solutions, iii) Exploring linkages with small towns and cities, iv) Accelerating the role of rural areas in low-carbon circular economy, v) Promoting digital transformation. [49] All presented European cases have/are receiving funds from European Commission, although some of them are carried out within the single project/ funding option, whereas other are actually an agglomeration of different projects directed toward achieving specific objective - such is for example the Arctic Smartness project, comprised of the clusters and financed by various funding schemes/mechanisms.

According to ESPON Policy brief on Shrinking rural regions in Europe [35], EU territory is experiencing depopulation of rural areas. The demographic challenges were especially addressed in the cases of Hungary and Italy, as the regions under considerations are characterized by agricultural activities and high rates of unemployment. Smart development solutions were therefore mainly addressing the ways to create opportunities for local employment and ease the living conditions. On the other hand the role of transition to circular economy has been accelerated in the case of Lapland where the main issue to address was to stop the outflow of the money especially in connection to the energy and food self-sufficiency. In the case of German smart villages the digital transformation was at the fore front. The region is one of the richest in the country and does not suffer for the depopulation of the area. To invest in digital connectivity within the villages and also within the broader regional community, was therefore also to improve opportunities for local/regional and circular economy and to enhance the sustainable development of the area. All the project cases/initiatives show how important is to look for strategies and solutions based on local or regional knowledge, even more so when striving for sustainable future.

To conclude our evaluation it is also important to note, that there are some considerable differences when dealing with rural areas in Europe and elsewhere as it is necessary to consider local and regional specifics. We have shown this on the case of some global initiatives and their specific developmental efforts and activities. The main difference is, that in Europe the basic infrastructure is already established whereas in some other "un-developed" regions the infrastructure is yet to be established.

The strategy of our forthcoming project SmartVillages will be founded on the insights offered by the above listed projects and initiatives and on our own experiences. SmartVillages is creating an effective partnership between actors important for the Alpine space region. The main argument, funded on the basis of our own already existing experiences and experiences of other approaches is that rural areas are not uniform, and that smart development has to be applied in combination with place-based approach. In our context the approach has to be in line with cultural and geographical 
specifics of Alpine space area, as well as with more specific local characteristics. In line with this, one of main outputs of SmartVillages project will be digital exchange platform intended for the exchange of practices. Another important output will be embodied in the form of Smart Villages Toolbox, based on insights from our pilot, local-based activities. As such it will have a great impact on further development and implementations of the concept into reality-based environments and will contribute to better framework conditions for (digital) innovation in societal and technical part.

Acknowledgements: This paper has been produced within the Smart digital transformation of villages in Alpine space (Smart Villages) project, which was funded by Interreg Alpine Space (20182021).

Author Contribution: Emilija Stojmenova Duh designed and supervised the research. All three authors, Veronika Zavratnik, Andrej Kos, and Emilija Stojmenova Duh have performed the research and analyzed the data. Veronika Zavratnik wrote the paper.

Conflict of Interest: The authors declare no conflict of interest. The founding sponsors had no role in design of the study; in the collection, analyses, or interpretation of data; in the writing of the manuscript, and in the decision to publish the results. All authors read and approved the final manuscript.

\section{References}

1. \#Envision2030: 17 Goals to Transform the World for Persons with Disabilities. Available online: https://www.un.org/development/desa/disabilities/envision2030.html (accessed 7 May 2018).

2. Jucevičius, Robertas; Patašiene, Irene; Patašius, Martynas. Digital dimension of smart city: critical analysis. Procedia - Social and Behavioural Sciences 2014, Vol. 156, pp. 146-150, doi:10.1016/j.sbspro.2014.11.137. Available online: https://www.sciencedirect.com/science/article/pii/S1877042814059576 (accessed on 3 May 2018).

3. Edwards, Mary, M.; Haines, Anna. Evaluating smart growth: Implications for small communities. Journal of Planning Education and Research 2007, 27, pp. 49-64, doi: 10.1177/0739456X07305792. Available online: http://journals.sagepub.com/doi/abs/10.1177/0739456X07305792 (accessed 3 May 2018).

4. European Network for Rural Development, Smart Villages. Available online: https://enrd.ec.europa.eu/smart-and-competitive-rural-areas/smart-villages_en (accessed 4 May 2018).

5. P., Srivatsa. Rural Urban Migration: Disturbing the Equilibrium between Smart Cities and Smart Villages. FIIB Business review, 2015, 3(4), pp. 3-10. Available online: http://journals.sagepub.com/doi/abs/10.1177/2455265820150301 (accessed 3 May 2018).

6. Gascó-Hernandez, Mila. Building a Smart City: Lessons from Barcelona. Communications at the ACM, 2018, 61(4), pp. 50-58, doi: 10.1145/3117800. Available online: https://cacm.acm.org/magazines/2018/4/226370building-a-smart-city/fulltext (accessed 10 May2018).

7. Naldi, Lucia; Nilsson, Pia; Westlund, Hans; Wixe, Sofia. What is smart rural development? Journal of Rural Studies, 2015, 40, pp. 90-101, doi: 10.1016/j.jrurstud.2015.06.006. Available online: https://www.sciencedirect.com/science/article/pii/S0743016715300024 (accessed 8 May 2018).

8. Orbàn, Annamària. Building Smart Communities in the Hungarian Social Economy. Community Development Journal, 2017, 52(4), pp. 668-684, doi: 10.1093/cdj/bsv053. Available online: https://academic.oup.com/cdj/article/52/4/668/2607782 (accessed 3 May 2018).

9. Glasmeier, Amy; Christopherson, Susan. Thinking about Smart Cities. Cambridge Journal of Regions, Economy and Society, 2015, 8, pp. 3-12, doi: 10.1093/cjres/rsu034. Available online: https://dusp.mit.edu/sites/dusp.mit.edu/files/attachments/publications/Smart\%20Cities\%20CJRES\%20021 415.pdf (accessed 3 May 2018).

10. Hayat, Parvez. Smart Cities: A Global Perspective. India Quarterly, 2016, 72(2), pp. 177-191, doi: 10.1177/0974928416637930. Available online: http://bprd.nic.in/WriteReadData/Bannerpdf/India\%20Quarterly-\%20A\%20Journal\%20of\%20Internationa 1\%20Affairs-2016-Hayat-177-91.pdf (accessed 3 May 2018). 
11. EU Smarti Cities Information System, About the Smarti Cities Information System. Available online: https://smartcities-infosystem.eu/content/about-smart-cities-information-system-scis (accessed 9 May 2018).

12. Saliva, M.; Cornacchia, C.; Di Renzo, G. C.; Braccio G.; Annuziato, M.; Colangelo, A.; Orifici, L.; Lapenna, V. Promoting Smartness among Local Areas in Southern Italian Region: The Smart Basilicata Project. Indoor and built Environment, 2016, 25(7), pp. 1024-1038, doi: 10.1177/1420326X16659328. Available online: http://journals.sagepub.com/doi/abs/10.1177/1420326X16659328 (accessed 3 May 2018).

13. Ekosmart, O projektu. Available online: http://ekosmart.net/sl/o-projektu/ (accessed 3 May 2018).

14. EU Action for SMART VILLAGES. Available online: https://ec.europa.eu/agriculture/sites/agriculture/files/rural-development-2014-2020/looking-ahead/rurdev-small-villages_en.pdf (accessed 3 May 2018).

15. Van Gevelt,T.; Canales Holzeis, C.; Fennell, S.; Heap, B.; Holmes, J.; Hurley Depret, M.; Jones, B.; Safdar, M. T. Achieving Universal Energy Access and Rural Development through Smart Villages. Energy for Sustainable Development, 2018, 43, pp. 139-142, doi: 10.1016/j.esd.2018.01.005.

16. Smart Villages, New Thinking for Off-Grid Communities Worldwide. Available online: http://e4sv.org/about-us/what-are-smart-villages/ (accessed 3 May 2018).

17. IEEE Smart Village. Available online: http://ieee-smart-village.org/ (accessed 3 May 2018).

18. Poggi, Francesca; Firmino, Ana; Amado, Miguel. SMART RURAL: A Model for Planning Net-Zero Energy Balance at Municipal Level. Energy Procedia, 2017, 122, pp. 56-61, doi: 10.1016/j.jgypro.2017.07.287. Available online: https://www.sciencedirect.com/science/article/pii/S1876610217328825 (accessed 10 May 2018).

19. Poggi, F.; Firmino, A.; Amado, M. Moving Forward on Sustainable Energy Transitions: The Smart Rural Model. European Journal of Sustainable Development, 2015, 4(2), pp. 43-50, doi: 10.14207/ejsd.2015.v4n243. Available online: https://ojs.ecsdev.org/index.php/ejsd/article/view/235/226 (accessed 10 May 2018).

20. Smart City Mission Transformation, Mission Statement \& Guidelines. Accessible online: http://164.100.161.224/upload/uploadfiles/files/SmartCityGuidelines(1).pdf (accessed 8 May 2018).

21. Smart Villages, Providing Global Means to Local Needs. Available online: http://smartvillages.org/Default.aspx (accessed 9 May 2018).

22. Digital India - Making Villages 'Smart', Amit Sharma. Available online: https://telecom.economictimes.indiatimes.com/tele-talk/digital-india-making-villages-smart/719 (accessed 3 May 2018).

23. Singapore tops global smart city performance ranking in 2017: study, Navin Sregantan. Available online: http://www.businesstimes.com.sg/government-economy/singapore-tops-global-smart-city-performanceranking-in-2017-study (accessed 9 May 2018).

24. Startup My City, Smart and Sustainable Cities in Asia. Available online: http://socialinnovation.hitachi/sg/about/startupmycity/pdf/EIU-Startup-My-City-Briefing-Paper.pdf ～(accessed 10.5.2018).

25. Cork 2.0 Declaration 2016, A Better Life in Rural Areas. Available online: https://ec.europa.eu/agriculture/sites/agriculture/files/events/2016/rural-development/cork-declaration-20_en.pdf (accessed 3 May 2018).

26. Smart Villafes, Bled Declaration. Available online: http://pametne-vasi.info/wpcontent/uploads/2018/04/Bled-declaration-for-a-Smarter-Future-of-the-Rural-Areas-in-EU.pdf (accessed 3 May 2018).

27. EU Commission, Agriculture and Rural Development. Available online: https://ec.europa.eu/agriculture/rural-development-2014-2020_en (accessed 9 May 2018).

28. Progetto SMART Basilicata. Available online: http://smartbasilicata.tern.it/ (accessed 9 May 2018).

29. Digitale Dörfer. Available online: https://www.digitale-doerfer.de/ (accessed 10 May 2018).

30. Digital Villages Germany. Available online: https://enrd.ec.europa.eu/sites/enrd/files/tg_smartvillages_case-study_de.pdf (accessed 10 May 2018).

31. Distributed Hotel Konjice. Available at: https://distributedhotel.si/ (accessed 10 May 2018).

32. Stojmenova Duh, Emilija; Kos, Andrej: Fablabs as drivers for open innovation and co-creation to foster rural development. In 2016 International Conference on Identification, Information and Knowledge in the Internet of Things, Proceedings of the 2016 International Conference on Identification, Information and Knowledge in the Internet of things (IIKI), Beijing, China, 20-21.10.2016, doi: 10.1109/IIKI.2016.70. Available online: https://ieeexplore.ieee.org/document/8281202/ (accessed 12 June 2018). 
33. Aggarwal, P.; Zougmorè, R.; Kinynagi, J.: Climate_Smart Villages: A community approach to sustainable agricultural development. Copenhagen, Denmark: CIGAR Research Program on Climate Change, Agriculture and Food Security (CCAFS). Available online: https://cgspace.cgiar.org/bitstream/handle/10568/33322/CCAFSClimateSmartVillages2013.pdf?sequence=9\&isAllowed $=y$ (accessed 12 June 2018).

34. Climate-Smart Villages. Available online: https://ccafs.cgiar.org/climate-smart-villages\#.Wyarc6czbIU (accessed 12 June 2018).

35. Policy brief: Shrinking rural regions in Europe. Available online: https://www.espon.eu/rural-shrinking (accessed 12 June 2018).

36. ESPON. Available online: https://www.espon.eu/programme/espon/espon-2020-cooperation-programme (accessed 17 June 2018).

37. The Leader Approach: A basic guide. Office for official publications of the European Communities, Luxembourg, $2006 . \quad$ Available online: https:/ec.europa.eu/agriculture/sites/agriculture/files/publi/fact/leader/2006 en.pdf (accessed 17 June 2018).

38. LEADER/CLLD. Available online: https://enrd.ec.europa.eu/leader-clld_en (accessed 17 June 2018).

39. Bridging the Rural-Urban Divide: Rural-urban partnerships in the EU. Available online: http://www.europarl.europa.eu/RegData/etudes/BRIE/2016/573898/EPRS_BRI(2016)573898_EN.pdf (accessed 18 June 2018).

40. Bocinell, Fabio; Pagnotta, Gabriele; Riccioli, Francesco; Casini, Leonardo. The determinants of quality of life in rural areas from a geographic perspective: the case of Tuscany. Review of urban E regional development studies, vol. 27, No. 2, pp. 104-117, doi: 10.1111/rurd.12035. Available online: https://onlinelibrary.wiley.com/doi/abs/10.1111/rurd.12035 (accessed 12 June 2018).

41. Hess, Steffen. Digital Villages Platform. Available online: https://enrd.ec.europa.eu/sites/enrd/files/tg1_smart-villages_digital-villages-platform hess.pdf (accessed 21 June 2018).

42. What is a Fab City? Available online: http://fab.city/ (accessed 22 June 2018).

43. Diez, Tomas. Personal Fabrication: Fab Labs as Platforms for Citizen-Based Innovation, from Microcontrollers to Cities. Nexus Netw J 2012, vol. 14, No. 3, pp.457-468, doi: 10.1007/s00004-012-0131-7. Available online: https://link.springer.com/content/pdf/10.1007\%2Fs00004-012-0131-7.pdf (accessed 22 June 2018).

44. FabLab Network Slovenia. Available online: http://fablab.si/en/ (accessed 22 June 2018).

45. SMART EUROPE. Available online: http://www.interreg4c.eu/projects/project-details/index-project=130smart-strategies-to-create-innovation-based-jobs-in-regions-of-europe\&.html (accessed 3 July 2018).

46. I. General Characteristic of the Practice. Available online: https://www.smarteurope.eu/sites/default/files/Job-creation Turistvandi.pdf (accessed 3 July 2018).

47. Arctic Smart Rural Community Cluster: Cluster report, December 2015. Available online: http://luotsi.lappi.fi/c/document library/get file?folderId=1664044\&name=DLFE-29555.pdf (accessed 22 June 2018).

48. Arctic Smartness Excellent news: Success Stories of the Lapland's Smart Specialisation. Available online: https://arcticsmartness.eu/wp-content/uploads/2018/03/AS-tabloid english web.pdf (accessed 4 July 2018).

49. Smart Villages: Revitalising Rural Services. EU Rural Review 2018, No. 26. Available online: https://enrd.ec.europa.eu/sites/enrd/files/enrd publications/publi-enrd-rr-26-2018-en.pdf (accessed 4 July 2018).

50. EU Comission: Growth: Internal Market, Industry, Entrepreneurship and SMEs: North Great Plain. Available online: https://ec.europa.eu/growth/tools-databases/regional-innovation-monitor/baseprofile/north-great-plain (accessed 4 July 2018).

51. EU Commission: Growth: Internal Market, Industry, Entrepreneurship and SMEs: Basilicata. Available online: https://ec.europa.eu/growth/tools-databases/regional-innovation-monitor/base-profile/basilicata (accessed 3 July 2018).

52. UrbiStat: Region of Bvailicata. online: https://ugeo.urbistat.com/AdminStat/en/it/demografia/dati-sintesi/basilicata/17/2 (accessed 3 July 2018). 
53. Pietrapertosa, Filomena; Chiarini, Roberta; Clerici Maestosi, Paola; Cosmi, Carmelina; Saliva, Monica. SMARTera Approach: A New Approach for Smart Participation through Social Urban Network, 2015. Available online: file:///C:/Users/veronikaz/Downloads/poster SUN4Matera Bolzano2015 FINALE\%20(4).pdf (accessed 3 July 2018).

54. EU Commission: Growth: Internal Market, Industry, Entrepreneurship and SMEs: Rhineland Palatinate. Available online: https://ec.europa.eu/growth/tools-databases/regional-innovation-monitor/baseprofile/rhineland-palatinate (accessed 3 July 2018).

55. Holmes, John, The Smart Villages Initiative: Findings 2014-2017; The Smart Villages Initiative: Cambridge, Great Britain, 2017. Available online: file:///C:/Users/veronikaz/Documents/Smart\%20Village/Sustainabilitiy\%20(gradivo\%20za\%20\%C4\%8Dla nek)/Dodatno\%20gradivo/The-Smart-Villages-Initiative-Findings-2014-2017 web.pdf (accessed 3 July 2018).

56. IEEE, Frequently Asked Questions: About IEEE Smart Village. Available online: http://ieee-smartvillage.org/wp-content/uploads/2015/09/IEEE_Smart_Village_FAQs_16SEPT15-2.pdf (accessed 5 July 2018).

57. CIGAR CCAFS, Climate Analogues. Available online: https://ccafs.cgiar.org/tool-climate-analoguetool\#.Wz24g9Iza72 (accessed 5 July 2018).

58. Statistic Times, Sector-wise contribution of GDP of India. Available online: http://statisticstimes.com/economy/sectorwise-gdp-contribution-of-india.php (accessed 5 July 2018). 